\title{
Determination of phosphorous oxoanions in pharmaceuticals using non-suppressed ion chromatography
}

\author{
M.A. Bello* and A.G. González \\ Department of Analytical Chemistry, Faculty of Chemistry, 41012 Seville, Spain
}

\begin{abstract}
The separation and quantitation of phosphorous oxoanions have been investigated by non-suppressed ion chromatography (IC) with conductometric detection using a modified gluconate-borate buffer as eluent. Hypophosphite being coeluted with the injection peak, its previous oxidation into phosphate is necessary. The method was applied to the determination of hypophosphite and phosphate in several pharmaceuticals.
\end{abstract}

Key words. Phosphate determination - hypophosphite determination - pharmaceuticals - non-suppressed ion chromatography conductometric detection.

\section{Introduction}

Phosphorous oxoanions are present in pharmaceutical formulations due to two sources: as active ingredients (orthophosphate and hypophosphite) or as salt forming agents, counter-ions of several organic active ingredients. In the first case, orthophosphate is used in hypercalcemia and as urinary acidificant. Hypophosphites, apart from its former use in the treatment of tuberculosis, are used as anabolyzing agents, by favouring the biosynthesis of proteins. In the second case, there are several therapeutic salts involving phosphate as counter-ion such as, for instance, codeine phosphate, pyridoxal phosphate or dexamethasone phosphate.

Phosphonoformate is a potent antivirus substance which produces, as degradation products phosphite and phosphate; it requires suitable analytical methods for its monitoring in biological fluids [1].

Phosphorous oxoanions, when present as minor or trace level, are currently determined spectrophotometrically, preferably as molybdenum blue or using the phosphovanadomolybdate method [2]. Phosphate is directly determined. Hypophosphite and phosphite are oxidized to phosphate prior their quantitation [2]. This standard procedure is tiresome compared with some recent procedures based on ion chromatography (IC). Tanaka et al. [3] and Biesaga and Trojanowicz [4] determined phosphorous oxoanions in plating solutions using the suppressed IC. Ryder [5] described the separation of phosphorous oxoanions by using singlecolumn IC with conductivity detector employing succinic acid ( $\mathrm{pH}$ 3) as eluent. Hatton and Pickering [6] analized phosphorous oxoanions and other inorganic anions using $\mathrm{p}$ hydroxybenzoic acid or p-aminobenzoic acid as suitable elu- ents and refractive index detection. Schmuckler et al. [7] proposed the use of gluconate-borate eluent for anion chromatography, which is actually, the eluent most widely used in non-suppressed or single column IC. Moreover, Waters Corporation commercializes a borate-gluconate type eluent for these purposes [8]. Ruiz et al. [9] used this eluent to determine inorganic water-soluble phosphate in vegetables. Bello and González [10] have been adapted the borate-gluconate procedure to determine phosphate in cola beverages.

The aim of the present paper is the study of separation and quantitation of hypophosphite, phosphite and phosphate by non suppressed IC with conductometric detection and its application to the determination of phosphorous oxoanions in drug formulations. The proposed procedure is fast, feasible, accurate and favourably compares with the time-consuming spectrophotometric methods. However, the price of the apparatus is much higher. Anyway, taking into account that standard HPLC systems are today available in the majority of research labs, the only extra requirements to apply our procedure will be an IC column and a conductometric detector.

\section{Materials and methods}

\section{Chromatographic system}

\section{Equipment}

A Waters 501 HPLC pump was used together with a Waters IC-Pak A HR packed with polymetacrylate resin with a quaternary ammonium functional group $(6 \mu \mathrm{m}$ particle size and 
exchange capacity of $30 \pm 3 \mu \mathrm{eq} \mathrm{mL}^{-1}$ ) fitted with a Waters Guard-Pak precolumn. Samples were injected by using a Rheodyne type injector with a $100 \mu \mathrm{L}$ loop. Detection was done from a Waters 341 Conductivity detector. Peak evaluations were done with an Hewlett Packard HP3395 integrator.

\section{Chromatographic conditions}

Eluent preparation: Prepare the concentrate solution A by dissolving $16 \mathrm{~g}$ of sodium gluconate, $18 \mathrm{~g}$ of boric acid and $25 \mathrm{~g}$ of sodium tetraborate in a mixture $25: 75 \mathrm{v} / \mathrm{v}$ of glycerol:water to $1 \mathrm{~L}$.

The working eluent is prepared by mixing $12 \mathrm{~mL}$ of concentrate solution A, $20 \mathrm{~mL}$ of $n$-butanol, $120 \mathrm{~mL}$ of acetonitrile and water up to 1 litre (pH 8.4). This eluent was degassed and micro-filtered $(0.2 \mu \mathrm{m})$ before use. Its conductivity was of about $180 \mu \mathrm{S}$ (\% Full Scale).

The flow rate was $1 \mathrm{~mL} \mathrm{~min}$. The detector operates at a Base range of $200 \mu \mathrm{S}$ and the integrator was used with an attenuation of 128 .

\section{Reagents}

Potassium permanganate (Merck), Potassium phosphate (Merck), phosphorous acid (Aldrich), sodium hypophosphite monohydrate (Fluka), boric acid (Merck), sodium gluconate (Fluka), sodium tetraborate decahydrate (Riedel), glycerol, n-butanol and acetonitrile (Merck) were of analytical reagent grade or better. Milli-Q treated water was used throughout.

Stock solutions of phosphate, phosphite and hypophosphite of $1000 \mathrm{mg} \mathrm{L}^{-1}$ were prepared and standardized if necessary.

For the sample mineralization, concentrated nitric acid and $30 \%$ hydrogen peroxide (Merck) were utilized.

\section{Samples}

Phosphate was determined in three antitusive formulations based on codeine phosphate (INISTON ANTITUSIVO ${ }^{\circledR}$, (Gayoso Wellcome), CODEISAN ${ }^{\circledR}$, (Abelló) and FIORINAL CODEINA ${ }^{\circledR}$, (Sandoz Pharma)). Hypophosphite was determined in three nutritional restoratives (CALCIOGEVE $^{\circledR}$, (Bama-Geve), OSVICAL ${ }^{\circledR}$, and OSVICALLISINA $^{\circledR}$, (Alter)). The composition of each formulation is given in the Appendix.

\section{Procedures}

\section{Sample treatments}

Samples containing phosphate were alkalized ( $\mathrm{pH}$ 8.5-9), diluted and passed through a Waters $\mathrm{C}_{18}$ SEP-Pak Plus cartridge (short body) before injection. Samples containing hypophosphite were digested with concentrated nitric acid and hydrogen peroxide in a sand bath near to dryness. Diluted portions were directly injected.

\section{Calibration features}

The chromatographic signal used in calibrations was the height peak ratio (with respect to the internal standard) according their reliability, better than peak area ratio.

A series $(n=10)$ of standard solutions (four replicates) of phosphorous oxoanions were prepared and measured. Data about the calibration graphs are collected in table I. Hypophosphite coelutes with the injection peak and a derivatization prior injection is required. So, standard solutions of hypophosphite were oxidized into phosphate with permanganate $0.5 \mathrm{M}$ in acidic medium [2]. The excess of permanganate was removed with $3 \%$ hydrogen peroxide.

The application of Student's t-test shows that the intercepts are insignificant and accordingly, the straight lines passe through the origin.

\section{Results and discussion}

The separation of hypophosphite, phosphite and phosphate, in the proposed mobile phase shows good resolution (Fig. 1). The species involved in the separation at the $\mathrm{pH}$ of the mobile phase were: $\mathrm{H}_{2} \mathrm{PO}_{2}^{-}, \mathrm{HPO}_{3}^{-2}$ and $\mathrm{HPO}_{4}^{2-}$. One characteristic of the non-suppressed IC with conductivity detection is the appearance of an injection peak; this is due to the displacement of the eluent ions by the injected ions [11]. Unfortunately, the peak corresponding to hypophosphite is very close to the injection peak, as can be seen in figure 1, and so, it coelutes with it. Accordingly, hypophosphite cannot be accurately quantitated directly from the chromatogram. It is more advisable to perform a derivatization into phosphate prior injection. If the sample contains both phosphate and hypophosphite, two injections are needed: with and without derivatization.

Table I. Calibration data.

\begin{tabular}{lcccc}
\hline Analyte & Regression parameters & LCR $^{a}$ & LOD $^{c}$ \\
\hline Phosphate & $y=(0.012 \pm 0.006)+(0.098 \pm 0.001) x$ & $0.5-10$ & 0.9994 \\
Phosphite & $y=(0.022 \pm 0.006)+(0.176 \pm 0.001) x$ & $0.5-8$ & 0.9990 \\
Hypophosphite $^{\mathrm{d}}$ & $y=(0.01 \pm 0.01)+(0.103 \pm 0.002) x$ & $0.5-10$ & 0.1 & 0.3 \\
\hline
\end{tabular}

${ }^{\mathrm{a}}$ Linear concentration range $\left(\mathrm{mg} \mathrm{L}^{-1}\right) ;{ }^{\mathrm{b}}$ Correlation coefficient; ${ }^{\mathrm{c}}$ Detection limit $\left(\mathrm{mg} \mathrm{L}^{-1}\right)$; ${ }^{\mathrm{d}}$ After derivatization (see text). 


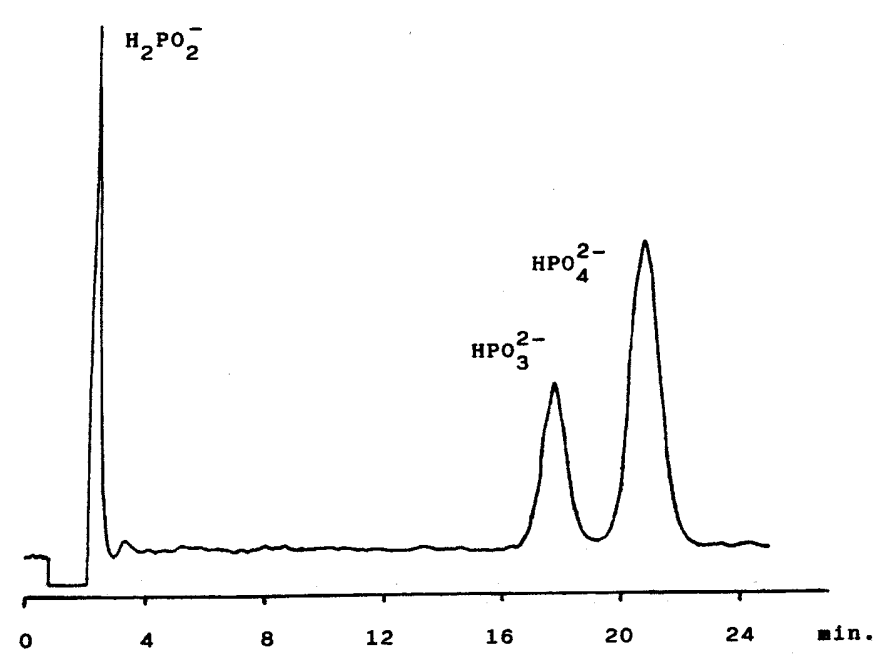

Fig. 1. Separation of phosphorous oxoanions by the described procedure. Injection of $100 \mu$ l containing $5 \mathrm{mg} \mathrm{L}^{-1}$ of each oxoanion.

Tanking into account that (apart from its appearance as a metabolite of phosphonoformate) phosphite is scarcely found in pharmaceutical formulations, the proposed procedure was applied only to samples containing phosphate or hypophosphite. The results obtained as percentage of the content of active ingredient claimed in the label for both the proposed method and a spectrophotometric method [2] are presented in table II. As can be observed, good agreement were found between both procedures. This was statistically proved according to the paired t-test [12] and also by considering the label claimed for analyzed samples, within the confidence limits accepted by pharmacopoeias.

\section{Conclusions}

The proposed IC method for determining phosphorous oxoanions is faster and easier than the conventional spectrophotometric procedures; however, investment is higher.
The necessity of hypophosphite derivatization is not a drawback because in mixtures, the spectrophotometric procedure requires the conversion of any phosphorous oxoanion into phosphate. The proposed IC method applied to several pharmaceutical formulations gives good results.

\section{Acknowledgements}

Authors thank to Waters Associates for providing the IC$\mathrm{Pak}^{\mathrm{TM}}$ A HR column for this work. Financial support from the DIGICYT of Spain through project PB92-0678 is gratefully acknowledged.

\section{Appendix}

Composition of the analyzed samples

CODEISAN $^{\circledR}$ (contents for $15 \mathrm{~mL}$ of syrup)

Codeine phosphate hemihydrate $19 \mathrm{mg}$

Ephedrine hydrochloride $\quad 30 \mathrm{mg}$

Sodium Benzoate $150 \mathrm{mg}$

Fluid extract of primrose $\quad 100 \mathrm{mg}$

Flavoured syrup, excipient up to $15 \mathrm{~mL}$

INISTON ANTITUSIVO ${ }^{\circledR}$ (contents for $5 \mathrm{~mL}$ of syrup)

Codeine phosphate hemihydrate $\quad 10.60 \mathrm{mg}$

Pseudoephedrine hydrochloride $\quad 28.25 \mathrm{mg}$

Tripolidine hydrochloride $\quad 1.40 \mathrm{mg}$

$\begin{array}{ll}\text { Sucrose (excipient) } & 3.5 \mathrm{~g}\end{array}$

FORINAL CODEINA $^{\circledR}$ (content for one capsule)

Codeine phosphate hemihydrate $\quad 14.67 \mathrm{mg}$

Caffeine anhydrous $\quad 40 \mathrm{mg}$

Acetaminophen $\quad 300 \mathrm{mg}$

Acetylsalicylic acid $200 \mathrm{mg}$

CALCIO GEVE ${ }^{\circledR}$ (contents for one effervescent tablet)

Calcium hypophosphite

$100 \mathrm{mg}$

Calcium levulinlactogluconate $\quad 500 \mathrm{mg}$

Table II. Percentage of the label claimed for the analysed samples obtained from the proposed method and from spectrophotometric methods (see text).

\begin{tabular}{lcccc}
\hline SAMPLE & \multicolumn{2}{c}{ HYPOPHOSPHITE } & & PHOSPHATE \\
& Proposed method & Spectrophotometric method & Proposed method & Spectrophotometric method \\
\hline Codeisán $^{\circledR}$ & - & - & $97.5 \%$ & $98.2 \%$ \\
Inistón Antitusivo $^{\circledR}$ & - & - & $96.2 \%$ & $97.1 \%$ \\
Fiorinal Codeina $^{\circledR}$ & - & - & $98.4 \%$ & $98.1 \%$ \\
Calcio Geve $^{\circledR}$ & $99.5 \%$ & $99.3 \%$ & - & - \\
Osvical $^{\circledR}$ & $101.7 \%$ & $100.9 \%$ & - & - \\
Osvical Lisina $^{\circledR}$ & $98.8 \%$ & $99.3 \%$ & - \\
\hline
\end{tabular}




\section{Letter}

Calcium heptagluconate

$500 \mathrm{mg}$

Vitamin C

$1000 \mathrm{mg}$

Vitamin $\mathrm{D}_{3}$

$3000 \mathrm{IU}$

Sodium benzosulphimide

$7 \mathrm{mg}$

OSVICAL $^{\circledR}$ (contents for one effervescent tablet)

Calcium hypophosphite

$686 \mathrm{mg}$

Calcium levulinate-carbonate $\quad 846 \mathrm{mg}$

Vitamin C

$500 \mathrm{mg}$

Cholecalciferol

$100 \mathrm{IU}$

Saccharine

$60 \mathrm{mg}$

OSVICAL LISINA ${ }^{\circledR}$ (contents for one tablet)

Calcium hypophosphite

$300.00 \mathrm{mg}$

Calcium ascorbate

$560.00 \mathrm{mg}$

Calcium pantoneate

Carnitine hydrochloride

Cobamamide

Ergocalciferol

Lisine hydrochloride

Calcium adipate

Calcium carbonate

Calcium citrate
$5.00 \mathrm{mg}$

$200.00 \mathrm{mg}$

$0.15 \mathrm{mg}$

$250.00 \mathrm{mg}$

$50.00 \mathrm{mg}$

$100.00 \mathrm{mg}$

$1315.00 \mathrm{mg}$.
$12.50 \mu \mathrm{g}$

\section{References}

1. Forsman, U.; Andersson, M.; Tönros, H. J. Chromatogr. 1986, 369, 151-157.

2. Williams, W. J. Handbook of anion determination; Butterworths: London, 1979; pp 487 and 435.

3. Tanaka, T.; Hiiro, K.; Kawahara, A.; Wakida, S. Bunseki Kagaku 1983, 32, 771-773.

4. Biesaga, M.; Trojanowicz, M. J. Chromatogr. 1995, 705, 390395.

5. Ryder, D. S. J. Chromatogr. 1986, 354, 438-441.

6. Hatton, D.; Pickering, W. F. Talanta 1993, 40, 307-311.

7. Schmuckler, G.; Jagoe, A. L.; Girard, J. E.; Buell, P. E. J. Chromatogr. 1986, 356, 413-419.

8. Water Ion Chromatography Cookbook; Millipore Corporation, Water Chromatography Division, Manual number 20195, Mildford, 1989.

9. Ruiz, E.; Santillana, M. I.; Nieto, M. T., Sastre, I. J. Liq. Chromatogr. 1995, 18, 989-1000.

10. Bello, M. A.; González, A. G. J. Chem. Education 1996, 73(12), 1174-1176.

11. Schmuckler, G.; Brenman, L. LC-GC Int. 1992, 5, 36-38.

12. Miller J.C.; Miller, J.N. Statistics for Analytical Chemistry; 3rd edition, Ellis Horwood-Prentice Hall: Chichester, 1993. 